\title{
Pilot Study on Treatment of Wastewater from an Ethylene Plant with Membrane Bioreactor Technology
}

\author{
Jian-Jun Qin*,1, Maung Htun Oo ${ }^{1}$, Guihe Tao $^{1}$, Kiran Arun Kekre ${ }^{1}$, Bryan Cashion ${ }^{2}$ and \\ Robert Wenta ${ }^{3}$
}

\author{
${ }^{I}$ Centre for Advanced Water Technology, PUB Consultants Pte Ltd, 80/82 Toh Guan Road East, \#C4-03, Singapore \\ 608575 \\ ${ }^{2}$ ExxonMobil Chemical Company (retired), Baytown, TX, USA \\ ${ }^{3}$ Siemens Water Technologies Corp., 301 West Military Road, Rothschild, WI 54474, USA
}

\begin{abstract}
Pilot studies were conducted with an anoxic/aerobic concept membrane bioreactor (MBR) technology and a hollow fiber Petro ${ }^{\circledR}$ MBR system with capacity of $12 \mathrm{~m}^{3} / \mathrm{d}$ was operated continuously (24-hour) during the study. Trials on different membrane fluxes were conducted to obtain the sustainable flux while mixed liquor suspended solid (MLSS) was maintained at 9-11 g/L. The results of the MBR pilot trials showed that no obvious fouling of the membrane was found when the plant was operated at the flux of $12 \mathrm{~L} / \mathrm{m}^{2} / \mathrm{h}(\mathrm{LMH})$ over 3 months and $15 \mathrm{LMH}$ over one month during the pilot study. Design guidelines such as hydraulic retention time (HRT), sludge retention time (SRT), anoxic and aeration volume ratio, re-circulation flow rate and air scouring were obtained for a full-scale plant. It was concluded that treatment of wastewater from an ethylene plant without addition of any chemicals using MBR technology is feasible. The product quality consistently met the requirement for discharge and was suitable for the feed of further reverse osmosis (RO) post-treatment.
\end{abstract}

Keywords: Membrane bioreactor, ethylene wastewater, COD removal, nitrification, wastewater treatment and reuse.

\section{INTRODUCTION}

Advanced membrane bioreactor (MBR) which is a combination of the conventional activated sludge process (ASP) and Microfiltration/Ultrafiltration membrane separation has been widely used in treatment of domestic sewage as MBR has advantages of consistently high quality of effluent, small footprint, reduced sludge production and simple system operation and facility management over ASP [1-14]. Stephenson et al. [2] have introduced a number of MBRs for treatment of municipal wastewater. Various commercial MBRs have proven both robustness of the process and reliable and simple operation. Gander et al. [4] have studied different types of commercial MBRs for domestic wastewater treatment with cost considerations and indicated that the submerged configuration with sucking the product from the inside of membranes would be more cost effective in operation than the side-stream configuration with pressuring the product from the inside to outside of membranes. Judd [9] has reviewed the MBR technology with focus on principles and applications of MBRs. Tao et al. [12,13] have investigated different types of submerged MBRs under the tropical conditions and demonstrated the advantages of MBR technology for reclamation of the domestic sewage.

Very recently, Viero et al. [15] have studied the effect of long-term feeding of high organic loading in a submerged

*Address correspondence to this author at the Centre for Advanced Water Technology, PUB Consultants Pte Ltd, 80/82 Toh Guan Road East, \#C4-03, Singapore 608575; Tel: +65-63262914; Fax: +65-63262929;

E-mail: jjqin@cawt.sui.com.sg
MBR treating oil refinery wastewater and showed high removal efficiency for both organic and phenols that proved the ability of the MBR technology to tackle high strength feed. However, there are limited studies of MBR technology on the treatment and reuse of petrochemical wastewater [16, 17]. Especially, challenges exist to deal with the ethylene wastewater with high concentrations of ammonia or oil \& grease $(O \& G)$ and shock-loading of sulphide. Nevertheless, tightening effluent regulations have generated interest in the treatment of petrochemical wastewater with the advanced MBR process. An existing wastewater treatment facility in a ExxonMobil Chemical Operations Private Limited (Singapore) facility consists of oil-water separation, equalization, additional oil-water separation and conventional activated sludge process. Waste activated sludge treatment includes aerobic digestion and dewatering on a belt filter press. The treated water is discharged to sea in compliance with Singaporean effluent limitations. The facility wanted to investigate enhancement of its existing effluent treatment system. MBR was considered to be a viable solution for achieving better treated water quality and possible product water recycling. The objectives of this study were to evaluate the feasibility of treating the ethylene wastewater to meet the applicable discharge limits consistently using a submerged Petro ${ }^{\circledR}$ MBR and further to evaluate whether the quality of the treated water would meet reuse requirements.

\section{MATERIALS AND METHODS}

The feed water for the MBR pilot plant was tapped from a point after the equalization tank and before the conventional activated sludge process at the waste water treatment 


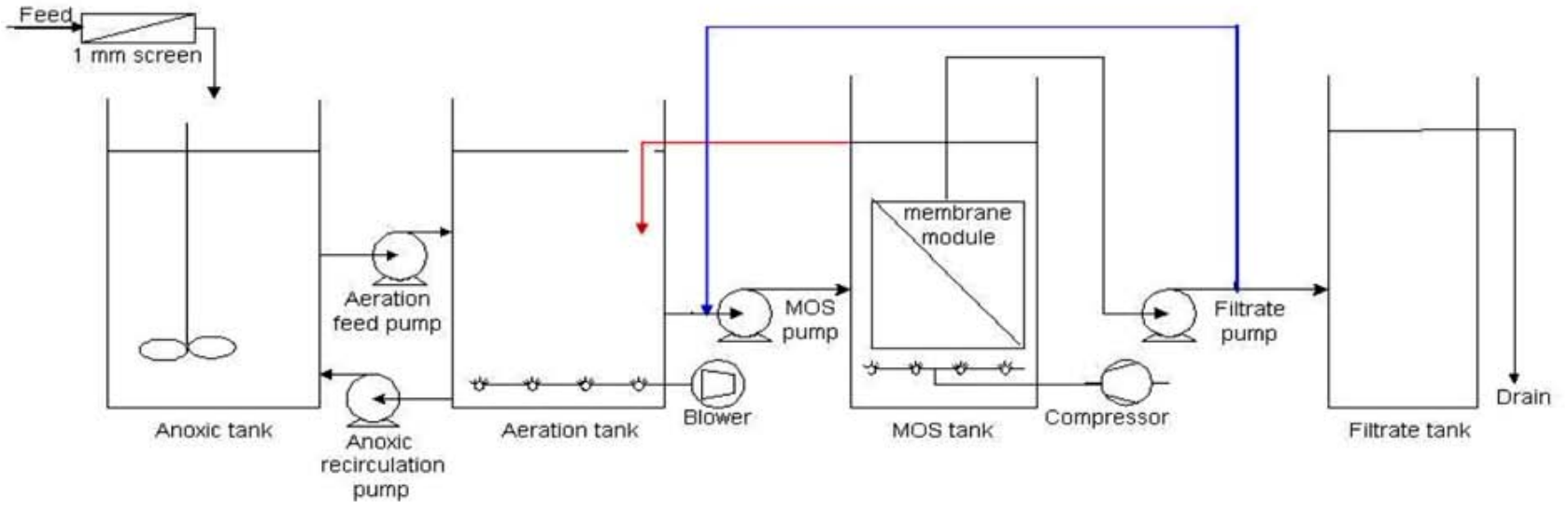

Fig. (1). Schematic process flow diagram of MBR pilot plant.

plant (WWTP) of the facility. Fig. (1) shows a schematic process flow diagram with an anoxic/aerobic concept. In the process, denitrification happens and nitrate is converted to nitrogen in the anoxic tank, and nitrification takes place and ammonium is converted to nitrate in the aeration tank while BOD and COD are biologically digested in both tanks. The membranes as filters allow clean water to pass but retain the activated sludge in the membrane operation system (MOS) tank. Hollow fibre membranes from Siemens Water Technologies were used for the trials. Specification of the MBR pilot plant is given in Table 1. The operating conditions of MBR system are shown in Table 2. The MBR pilot plant was operated continuously (24-hour) during the study and the operation was controlled by a programmable logic controller (PLC).

Table 1. Specification of MBR Pilot Plant

\begin{tabular}{|c|c|}
\hline Item & Specification \\
\hline \hline Membrane type & Hollow fibre \\
\hline Membrane material & Polyvinylidene Fluoride (PVDF) \\
\hline $\begin{array}{c}\text { Membrane pore size } \\
\text { Inner diameter/outer diameter of } \\
\text { fibre }\end{array}$ & $0.04 \mu \mathrm{m}$ (nominal) \\
\hline Membrane area & $0.7 \mathrm{~mm} / 1.2 \mathrm{~mm}$ \\
\hline Effective volume of anoxic tank & $37.5 \mathrm{~m}^{2}$ \\
\hline Effective volume of aeration zone & $1.87 \mathrm{~m}^{3}$ \\
\hline
\end{tabular}

Trials on different membrane fluxes were conducted to obtain the sustainable flux. On Day 1, the MBR pilot plant was seeded from the existing activated sludge system. On Day 3, full operation of the pilot plant started at the net membrane flux of $6 \mathrm{LMH}$ which was then gradually increased to 8, 10 and $12 \mathrm{LMH}$ with zero sludge wastage on Day 5, Day 12 and Day 33, respectively. After that, the pilot plant continued the operation at the net flux of $12 \mathrm{LMH}$ until Day 75 with wasting excess MLSS from the aeration tank at 300L/day from Mondays to Fridays. Due to an unexpected accident on the first membrane module which was replaced with a new one on Day 107, the pilot plant was operated at the net flux of $15 \mathrm{LMH}$ with the second module from Day 113 onward. Maintenance clean (MC) with 200 $\mathrm{mg} / \mathrm{L}$ of $\mathrm{NaOCl}$ solution was done twice per week during the operation.

MLSS in the aeration tank started from $4.5 \mathrm{~g} / \mathrm{L}$, gradually increased to $9 \mathrm{~g} / \mathrm{L}$, and was then maintained at $9-11 \mathrm{~g} / \mathrm{L}$ during the study. Air flow for the aeration tank was $1.6 \mathrm{~m}^{3} / \mathrm{min}$ or $2.56 \mathrm{~m}^{3} / \mathrm{h}$ per $\mathrm{m}^{2}$ membrane area, which was relatively high. It could be attributed to the high chemical oxygen demand (COD) in the influent, small effective aeration tank depth of $2.3 \mathrm{~m}$ and low limit run of the aeration tank blower at $68 \%$ which resulted in an overcapacity run state (most of the time). Optimization of this condition in a full scale plant would be expected. Air scouring for the membrane was provided at $0.264 \mathrm{~m}^{3} / \mathrm{h}$ per $\mathrm{m}^{2}$ membrane area, which is commonly acceptable in a full scale plant.

\section{RESULTS AND DISCUSSION}

\section{Membrane Permeability at Different Fluxes}

Fig. (2) shows the membrane relative permeability (which is the ratio of specific flux at the time over that on Day 3) of the first membrane vs. time. The data before Day 10 were not presented. When the operation started at the flux of $6 \mathrm{LMH}$, the initial membrane relative permeability was 1.0 with MLSS concentration of $4512 \mathrm{mg} / \mathrm{L}$ in the aeration tank. When the flux was enhanced to $10 \mathrm{LMH}$ on Day 12, MLSS was increased to $7280 \mathrm{mg} / \mathrm{L}$. As a consequence, the relative permeability dropped to about 0.6 . When the flux was increased to $12 \mathrm{LMH}$ on Day 33 while MLSS was 8800 $\mathrm{mg} / \mathrm{L}$, the permeability further decreased to about 0.5 . After that, the flux was kept at $12 \mathrm{LMH}$, the permeability remained stable at around 0.5 until Day 70. However, permeability declined quickly toward 0.36 on Day 78 . The pilot plant was out of operation after Day 83 for a few days. The product was found to be contaminated with MLSS on Day 89. Thus, Clean-in-place (CIP) with hypo solution was conducted on Day 91 and membrane module was taken out for inspection. Loose connections between the cap and the module were found. Thus, a spring washer was added to secure the connection. When the pilot plant was restarted, permeability was recovered to 0.53 on Day 93 and quickly reduced to 0.35 on Day 102. When CIP was conducted again with citric acid solution, permeability only reached 0.48 . The quick reduction of the membrane permeability on both Day 78 and Day 93 as well as the poor efficiency of CIP might be due to 
Table 2. Operating Conditions of the MBR Pilot Plant

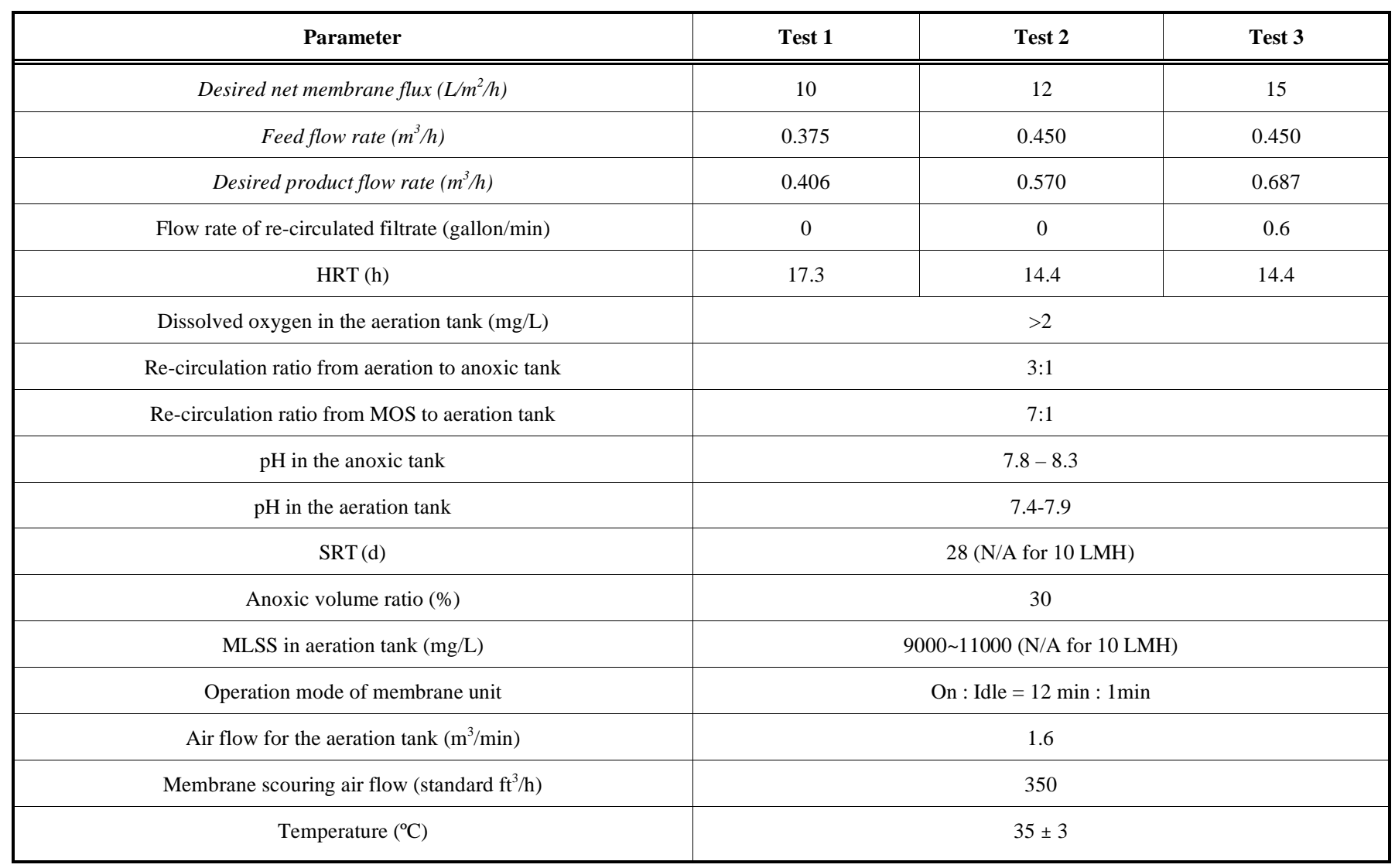

plugging of MLSS into fibers caused by an unexpected accident of the loose connections mentioned above.

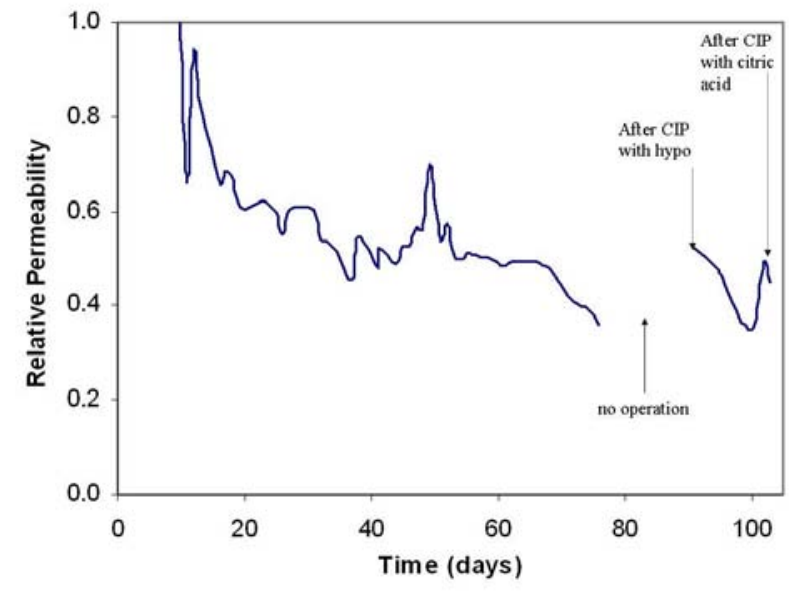

Fig. (2). Relative permeability of the 1 st membrane $v s$. time.

Because of unsatisfactory recovery of permeability after CIP with hypo and citric acid, it was decided to install the second membrane module to replace the first one on Day 107. Initial membrane net flux of the second membrane module was $10 \mathrm{LMH}$ on Day 109. The net flux was increased to $12 \mathrm{LMH}$ on Day 111 and 15 LMH on Day 113. HRT was maintained at 14.4 hours during the operation at 15 $\mathrm{LMH}$ by re-circulating the product to the feed line of the
MOS pump while the feed flow rate remained the same at $0.450 \mathrm{~m}^{3} / \mathrm{h}$. Fig. (3) shows the relative permeability vs. time. Permeability reduced from 1.0 at the beginning of $15 \mathrm{LMH}$ on Day 113 to 0.56 on Day 132 . Then, permeability seemed to be stable at 0.56 for about one week until Day 148. As the trans-membrane pressure (TMP) was $<0.08$ bar, which was really low compared to the target 0.4 bar for CIP, there would not be sufficient fouling to test the effectiveness of CIP. Encouraging results were observed at the flux of 15 $\mathrm{LMH}$ under the desired operating conditions during the five weeks.

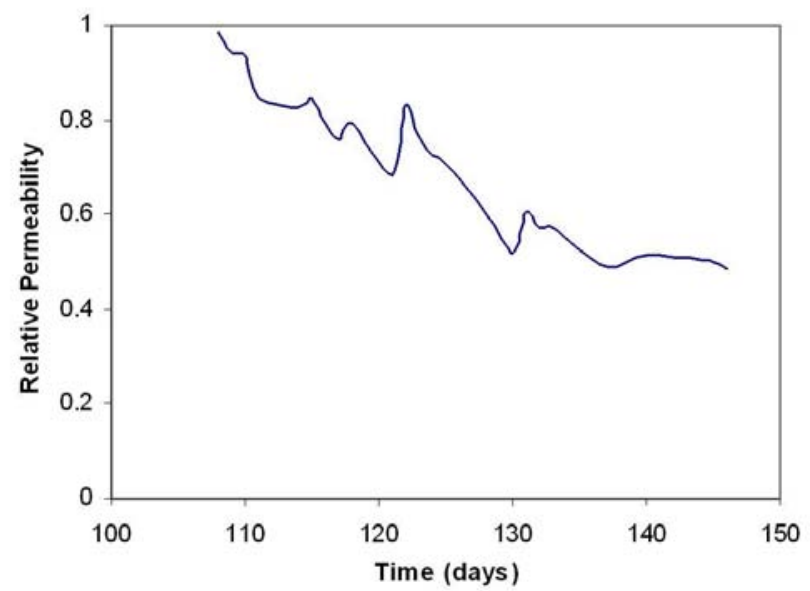

Fig. (3). Relative permeability of the 2nd membrane $v s$. time. 


\section{Stability of Biological Process}

Fig. (4) indicates nitrification efficiency, sulfide and O\&G contents in the feed during the pilot plant operation. Within one week from starting of the plant operation, the nitrification efficiency reached almost $100 \%$. The nitrification efficiency was low at $54 \%$ and $22 \%$ on Day 76 and Day 97 , respectively. The upset nitrification could be related to both the spikes of sulphide (more than $50 \mathrm{mg} / \mathrm{L}$ ) and $\mathrm{O} \& \mathrm{G}$ in the MBR feed. However, the impact did not last long and nitrification recovered within few days.

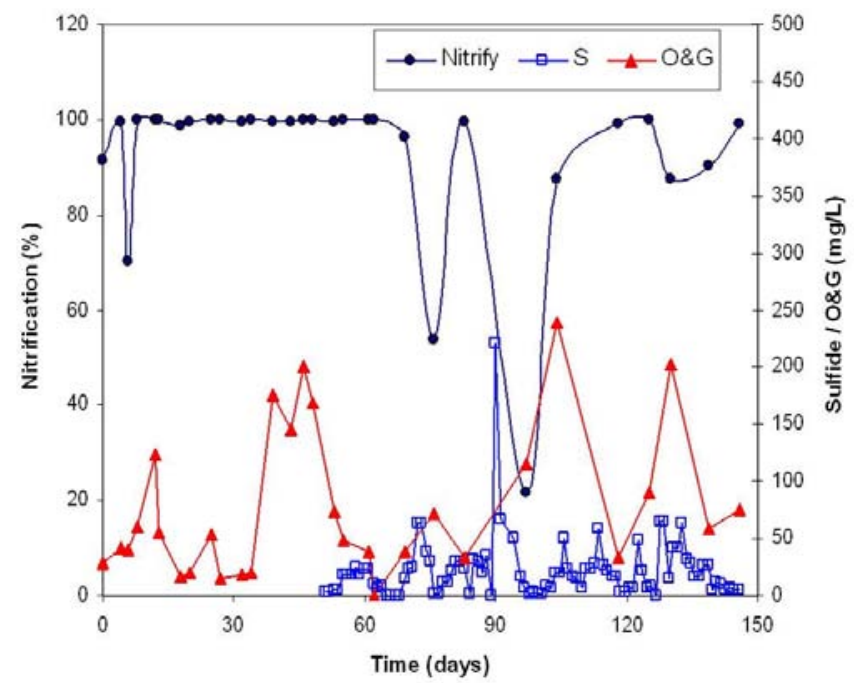

Fig. (4). Nitrification efficiency, sulphide and $O \& G$ content $s$ in the feed $v s$. time.

Table 3 shows the ranges of the biologically degradable or convertible parameters in feed, anoxic tank, aeration tank and product. It can be seen that COD and biological oxygen demand (BOD) in the feed fluctuated in the range of 940$1600 \mathrm{mg} / \mathrm{L}$ and $290-885 \mathrm{mg} / \mathrm{L}$, respectively. $\mathrm{NH}_{3}-\mathrm{N}$ and TKN in the feed were at high levels and fluctuated in the range of $54.4-114 \mathrm{mg} / \mathrm{L}$ and $57-122 \mathrm{mg} / \mathrm{L}$, respectively. When the operation was stable, BOD and COD in the anoxic tank were in the range of $13-32 \mathrm{mg} / \mathrm{L}$ and $108-371 \mathrm{mg} / \mathrm{L}$, respectively. If nitrification was disturbed, BOD and COD were higher with maximums at 65 and $574 \mathrm{mg} / \mathrm{L}$, respectively. During the stable operation, $\mathrm{NH}_{3}-\mathrm{N}$ in the anoxic tank was $11.25-33.9 \mathrm{mg} / \mathrm{L}$. $\mathrm{NH}_{3}-\mathrm{N}$ reached $88.7 \mathrm{mg} / \mathrm{L}$ in the anoxic tank when nitrification was upset. It might be due to high sulphide content in feed as shown in Fig. (4). Nitrite did not inhibit both nitrification and de-nitrification throughout the study because nitrite levels in both anoxic and aeration tanks were very low at $<0.1 \mathrm{mg} / \mathrm{L}$ (most of time). It is further confirmed that de-nitrification was not a concern because $\mathrm{NO}_{3}-\mathrm{N}$ in the anoxic tank was less than $1.1 \mathrm{mg} / \mathrm{L}$ throughout the study. $\mathrm{NH}_{3}-\mathrm{N}$ and $\mathrm{NO}_{3}-\mathrm{N}$ in the aeration tank were in the range of $0.7-6.52 \mathrm{mg} / \mathrm{L}$ and $1.3-16.8 \mathrm{mg} / \mathrm{L}$, respectively, indicating nitrification was satisfied. As a result, product $\mathrm{COD}$ and $\mathrm{NH}_{3}-\mathrm{N}$ are in the range of $31-74 \mathrm{mg} / \mathrm{L}$ and $0.1-$ $2.83 \mathrm{mg} / \mathrm{L}$ which are well within the water reuse specification indicated in Table 4 later.

In summary, biological process was generally quite stable during the study. There were a few occasions of sulphide spikes in the feed water which caused the upset of nitrification, however, nitrification in MBR system could be recovered within few days. Moreover, high concentration of oil \& grease in the feed did not show an impact on the biological process and membrane fouling.

\section{Analytical Results of Feed and Product Water}

Typical quality of feed and MBR product water is summarized in Table 4. Requirement for discharge and specification for water reuse are also given in Table 4 . The data shows that the MBR can produce a stable effluent even when the feed quality varies significantly. When the operation of MBR system was stable, COD and BOD concentrations in the product were $31-74$ and $2-5 \mathrm{mg} / \mathrm{L}$, respectively. Oil \& grease in the product was less than $10 \mathrm{mg} / \mathrm{L}$. $\mathrm{NH}_{3}-\mathrm{N}$ was $<3$ $\mathrm{mg} / \mathrm{L}$. Phosphate in the product was at $<0.80-3.98 \mathrm{mg} / \mathrm{L}$. It should be pointed out that $\mathrm{pH}$ of product was narrow in the range of 7.8-8.5 without addition of any chemical in the treatment process although the feed $\mathrm{pH}$ varied in a wide range of 6.9-9.4. TSS and turbidity of the product were $<2.5$ $\mathrm{mg} / \mathrm{L}$ and 0.1-0.3 NTU, respectively. As a consequence, the product quality in terms of the biologically degradable parameters and characterization related to the MF membrane filtration well met the requirement not only for discharge but also for reuse because good biological processes were achieved and the integrity of the membranes was good. In addition, silt density index (SDI) of the MBR product was 2.9 , indicating the product was suitable for RO feed.

Further analysis of the MBR product for inorganic parameters as shown in Table $\mathbf{5}$ indicates that sodium and sulphate in the product were the main components which caused high total dissolved solids (TDS). The TDS in the effluent precludes the use of all the MBR effluent for cooling water makeup. The final percentage of reuse will be determined after startup and the specific chemical program for the cooling water circuit is defined. In addition, total organic carbon (TOC) in the product was higher than the requirement for cooling tower makeup.

Table 3. Range of BOD, COD, $\mathrm{NH}_{3}-\mathrm{N}$ and $\mathrm{NO}_{3}-\mathrm{N}$ in Feed, Anoxic Tank, Aeration Tank and Product

\begin{tabular}{|c|c|c|c|c|c|c|}
\hline Sampling Point & BOD $(\mathbf{m g} / \mathbf{L})$ & $\mathbf{C O D}(\mathbf{m g} / \mathbf{L})$ & $\mathbf{N H}_{3}-\mathbf{N}(\mathbf{m g} / \mathbf{L})$ & $\mathbf{T K N}(\mathbf{m g} / \mathbf{L})$ & $\mathbf{N O}_{3}-\mathbf{N}(\mathbf{m g} / \mathbf{L})$ & $\mathbf{N O} \mathbf{O}_{2}-\mathbf{N}(\mathbf{m g} / \mathbf{L})$ \\
\hline \hline Feed & $290-885$ & $940-1600$ & $54.4-114$ & $57-122$ & $0.02-2.8$ & - \\
\hline Anoxic tank & $13-32$ & $108-371$ & $11.25-33.9$ & - & $0.01-1.1$ & $0.01-0.1$ \\
\hline Aeration tank & $9-28$ & $52-162$ & $0.7-6.52$ & - & $1.3-16.8$ & $0.01-0.1$ \\
\hline Product & $2-5$ & $31-74$ & -2.83 & $0.15-4.2$ & $8.6-28.4$ & $0.01-0.1$ \\
\hline
\end{tabular}


Table 4. Typical Quality of Feed and Product

\begin{tabular}{|c|c|c|c|c|}
\hline Parameter & Feed & Product & $\begin{array}{l}\text { Requirement for } \\
\text { Discharge }\end{array}$ & $\begin{array}{c}\text { Specifications of Water Reuse for } \\
\text { Cooling Tower Makeup }\end{array}$ \\
\hline $\mathrm{COD}(\mathrm{mg} / \mathrm{L})$ & $940-1600$ & $31-74$ & $<100$ & - \\
\hline BOD $(\mathrm{mg} / \mathrm{L})$ & $290-885$ & $2-5$ & $<50$ & $<5$ \\
\hline Oil \& grease $(\mathrm{mg} / \mathrm{L})$ & $15-239$ & $<10$ & $<10$ & - \\
\hline $\mathrm{PO} 4(\mathrm{mg} / \mathrm{L})$ & $<0.80-14.3$ & $<0.80-3.98$ & $<5$ & - \\
\hline $\mathrm{pH}$ & $6.9-9.4$ & $7.8-8.5$ & $6-9$ & - \\
\hline TSS (mg/L) & $12-511$ & $<2.5$ & $<30$ & $<5$ \\
\hline Turbidity (NTU) & -- & $0.1-0.3$ & - & - \\
\hline $\mathrm{TOC}(\mathrm{mg} / \mathrm{L})$ & $313-475$ & $13.4-26.6$ & - & $<10$ \\
\hline
\end{tabular}

Table 5. Product Quality (Inorganic)

\begin{tabular}{|c|c|c|}
\hline Parameter & Unit & Value \\
\hline \hline Arsenic & $\mathrm{mg} / \mathrm{L}$ & $0.013-0.020$ \\
\hline Calcium & $\mathrm{mg} / \mathrm{L}$ & $8.89-12.7$ \\
\hline Chloride & $\mathrm{mg} / \mathrm{L}$ & $137-169$ \\
\hline Chromium & $\mathrm{mg} / \mathrm{L}$ & $<0.007$ \\
\hline Copper & $\mathrm{mg} / \mathrm{L}$ & $<0.002$ \\
\hline Iron & $\mathrm{mg} / \mathrm{L}$ & $0.017-0.023$ \\
\hline Lead & $\mathrm{mg} / \mathrm{L}$ & $<0.013$ \\
\hline Magnesium & $\mathrm{mg} / \mathrm{L}$ & $5.48-6.40$ \\
\hline Mercury & $\mathrm{mg} / \mathrm{L}$ & $0.032-0.047$ \\
\hline Nickel & $\mathrm{mg} / \mathrm{L}$ & $0.004-0.006$ \\
\hline Phosphate & $\mathrm{mg} / \mathrm{L}$ & $<0.80-3.98$ \\
\hline Sodium & $\mathrm{mg} / \mathrm{L}$ & $1570-1830$ \\
\hline Sulphate & $\mathrm{mg} / \mathrm{L}$ & $2410-3195$ \\
\hline Si as SiO 2 & $\mathrm{mg} / \mathrm{L}$ & 2.57 \\
\hline Total alkalinity as CaCO3 & $\mathrm{mg} / \mathrm{L}$ & $365-406$ \\
\hline Zinc & $\mathrm{mg} / \mathrm{L}$ & $<0.004$ \\
\hline
\end{tabular}

\section{CONCLUSIONS}

From the results of the MBR pilot trials, the conclusions can be drawn as follows: (1) it is feasible to treat petrochemical wastewater using MBR technology. The product quality consistently met the requirement for discharge and was suitable for the feed of further RO post-treatment; (2) during the pilot study, no obvious fouling of the membrane was found when the plant was operated at the flux of 12 over
3 months and 15 LMH over one month; (3) HRT of 14 hours and SRT of 28 days, anoxic and aeration volume ratio of $30: 70$, re-circulation flow rate from the aeration tank to anoxic tank being 3 times of the feed flow rate, air scouring for the membrane at $0.264 \mathrm{~m}^{3} / \mathrm{h} / \mathrm{m}^{2}$ could be used as design guide for full-scale plant; (4) MC with $200 \mathrm{mg} / \mathrm{L}$ of hypo solution at the frequency of twice per week was found reasonable.

Recommendations in future work include to optimise air flow for the aeration tank, to verify low fouling tendency at higher flux for enhancement of production, to conduct RO post-treatment for reuse of the treated water and to conduct economic evaluation of the new process.

\section{ACKNOWLEDGEMENTS}

The authors acknowledge the support of ExxonMobil Chemical Operations Private Limited. The authors would like to thank Ms Grace Loh, Mr Jason Lim, Mr Michael Howdeshell and Mr Chee Meng Ang for their contributions in the study.

\section{REFERENCES}

[1] W. Ghyoot, and W. Verstraete, "Reduced sludge production in a two stage membrane assisted bioreactor", Water Res., vol. 34, pp. 205-215, 1999.

[2] T. Stephenson, S. Judd, B. Jefferson, and K. Brindle, Membrane Bioreactors for Wastewater Treatment. Padstow, Cornwall, UK: IWA Publishing 2001.

[3] S. Holler, and W. Trosch, "Treatment of urban wastewater in a membrane bioreactor at high organic loading rates", J. Biotechnol., vol. 92, pp. 95-101, 2001.

[4] M. Gander, B. Jefferson, and S. Judd, "Aerobic MBRs for domestic wastewater treatment: a review with cost considerations", Separation Purification Technol., vol. 18, pp. 119-130, 2000.

[5] P. Lawrence, S. Adham, and L. Barrott, "Ensuring water re-use projects succeed-institutional and technical issues for treated water re-use", Desalination, vol. 152, pp. 291-298, 2002.

[6] W. Lee, S. Kang, and H. Shin, "Sludge characteristics and their contribution to microfiltration in submerged membrane bioreactors". J. Membr. Sci., vol. 216, pp. 217-227, 2003.

[7] T.I. Yoon, H.S. Lee, and C.G. Kim, "Comparison of pilot scale performances between membrane bioreactor and hybrid conven- 
tional wastewater treatment systems", J. Membr. Sci., vol. 242, pp. 5-12, 2004.

[8] R.S. Trussell, S. Adham, and R.R. Trussell, "Process limits of municipal wastewater treatment with the submerged membrane bioreactor", J. Envir. Engrg., vol. 131, pp. 410-416, 2005.

[9] S. Judd, The MBR book - Principles and applications of membrane bioreactors in water and wastewater treatment, Oxford: Elsevier 2006.

[10] H. Fletcher, T. Mackley, and S. Judd, "The cost of a package plant membrane bioreactor”, Water Res., vol. 41, pp. 2627-2635, 2007.

[11] P. Le-Clech, V. Chen, and A.G. Fane, "Fouling in membrane bioreactors used for wastewater treatment - A review", J. Membr. Sci., vol. 284, pp. 17-53, 2006.

[12] J.J. Qin, K.A. Kekre, G. Tao, M.H. Oo, M.N. Wai, C.L. Ting, B. Viswanath, and H. Seah, "New option of MBR-RO process for production of NEWater from domestic sewage", J. Membr. Sci., vol. 272, pp. 70-77, 2006.
[13] G. Tao, K. Kiran, W. Zhao, C.L. Ting, V. Bala, and H. Seah, "Membrane bioreactors for water reclamation", Water Sci. Technol., vol.51, pp. 431-440, 2005.

[14] K.W. Chau, "Investigation on effects of aggregate structure in water and wastewater treatment", Water Sci. Technol., vol. 50, no. 12, pp. 119-124, 2004.

[15] A.F. Viero, T.M. De Melo, A.P.R. Torres, and N.R. Ferreira, "The effects of long-term feeding of high organic loading in a submerged MBR treating oil refinery wastewater", J. Membr. Sci., vol. 319, pp. 223-230, 2008.

[16] J.J. Qin, M.H. Oo, G. Tao, and K.A. Kekre, "Feasibility study on petrochemical wastewater treatment and reuse using submerged MBR”, J. Membr. Sci., vol. 293, pp. 161-166, 2007.

[17] D. Mourato, D. Thompson, and J. Penny, "Immersed membrane bioreactor for wastewater reclamation and reuse", in Membrane Technology for Wastewater Reclamation and Reuse Conference, Tel Aviv, Israel, September 9-13, 2001.

(C) Qin et al.; Licensee Bentham Open

This is an open access article licensed under the terms of the Creative Commons Attribution Non-Commercial License (http://creativecommons.org/licenses/by-nc/3.0/) which permits unrestricted, non-commercial use, distribution and reproduction in any medium, provided the work is properly cited. 